\title{
TINGKAT KEPUASAN PASIEN RAWAT JALAN TERHADAP KUALITAS PELAYANAN KEPERAWATAN DI PUSKESMAS TEMPE KABUPATEN WAJO
}

\author{
Ery Wardanengsih ${ }^{1}$, Syamsul Rijal ${ }^{2}$, A.Indrawati Mallapiang ${ }^{3}$ \\ ${ }^{1}$ Universitas Puangrimaggalatung Sengkang \\ ${ }^{2}$ Universitas Muslim Indonesia \\ ${ }^{3}$ Universitas Muslim Indonesia
}

Alamat Korespendensi: (erywardanengsih@gmail.com/082324429400)

\begin{abstract}
ABSTRAK
Puskesmas adalah unit satuan terdepan secara fungsional, administrasi dan fisik yang membawakan berbagai usaha-usaha pokok kesehatan disuatu daerah yang secara langsung memberikan pelayanan kepada masyarakat (Ryadi, 2002).Pelayanan kesehatan yang berkualitas adalah pelayanan kesehatan yang dapat memuaskan setiap pemakai jasa pelayanan kesehatan sesuai dengan tingkat kepuasan rata-rata penduduk serta penyelenggaraannya sesuai dengan kode etik dan standar pelayanan profesi yang ada. Dansky mengatakan bahwa pemuasan pelanggan atau pasien adalah prinsip dasar manajemen mutu kualitas (Palutturi, 2008). Tujuan penelitian ini adalah untuk mengetahui tingkat kepuasan pasien rawat jalan terhadap kualitas pelayanan keperawatan di Puskesmas Tempe kabupaten Wajo. Jenis penelitian yang digunakan adalah deskriptif dengan pendekatan cros sectional study pada pasien yang memanfaatkan pelayanan rawat jalan di poliklinik umum dan gigi. Data diperoleh dengan menggunakan kuisioner kualitas pelayanan dari segi penampilan fisik perawat, dari segi empaty perawat, dari segi daya tanggap perawat dan dari segi kehandalan. Data ditabulasi dan dilakukan interpretasi dengan menggunakan metode statistik untuk analisis univariat. Berdasarkan hasil penelitian yang telah dilakukan terhadap 33 responden pada masing-masing variabel menunjukan bahwa 28 responden $(84,8 \%)$ mempersepsikan perasaannya puas terhadap penampilan fisik perawat, 29 responden $(87,9 \%)$ mempersepsikan perasaannya puas terhadap empaty perawat, 27 responden $(81,8 \%)$ mempersepsikan perasaannya puas terhadap daya tanggap perawat dan 30 responden $(90,9 \%)$ mempersepsikan perasaannya puas terhadap kehandalan perawat. Kesimpulan dari penelitian ini bahwa tingkat kepuasan pasien rawat jalan terhadap kualitas pelayanan keperawatan baik itu dari segi penampilan fisik, empaty, daya tanggap dan kehandalan perawat di wilayanh kerja Puskesmas Tempe kabupaten Wajo berada pada tingkat kepuasan puas.
\end{abstract}

Kata Kunci : Kepuasan Pasien, Kualitas, Puskesmas

\section{PENDAHULUAN}

Paradigma sehat merupakan salah satu konsep pembangunan nasional yang berwawasan kesehatan untuk menuju pencapaian Indonesia sehat 2010 yang ditandai dengan masyarakat hidup dalam lingkungan dan dengan perilaku hidup sehat, memiliki kemampuan untuk menjangkau pelayanan kesehatan serta memiliki derajat kesehatan masyarakat tinggi (Depkes RI, 2005).Puskesmas Tempe merupakan puskesmas yang letaknya strategis dan jumlah kunjungan pasien sangat banyak. Tahun 2008 jumlah kunjungan rawat jalan periode JanuariDesember 36.083 pasien sedangkan jumlah kunjungan rawat jalan tahun 2009 periode Januari-Desember $41.363 \quad$ pasien. Berdasarkan survey pengaduan masyarakat terhadap pelayanan keperawatan puskesmas Tempe periode januari-juni Tahun 2010, sedikitnya terdapat 249 mengadukan pelayanan keperawatan yang kurang ramah (kurang senyum) dalam melayani pasien, dan 436 keluhan pasien mengenai keterlambatan perawat dalam memberikan pelayanan, sedangkan 849 pasien mengatakan komunikasi terhadap perawat tidak puas, 112 pasien mengatakan pelayanan keperawatan dilakukan secara adil, 85 pasien mengatakan kedisplinan perawat tidak puas dirasakan pasien, 241 pasien mengatakan kebersihan perawat tidak puas. Pelayanan keperawatan yang mendapat respon banyak dari pasien dilihat dari kunjungan dalam seminggu adalah pelayanan dari poliklinik umum dan gigi yaitu rata-rata 50 responden (Laporan Tahunan Puskesmas Tempe, 2010).

\section{BAHAN DAN METODE}

Lokasi, Populasi, dan Sampel

Lokasi Penelitian dilakukan di puskesmas

Tempe Kabupaten Wajo bagian rawat 
jalan,Waktu penelitian ini akan dilaksankan pada tanggal 20-25 Oktober 2010. Populasi adalah keseluruhan subyek penelitian yang akan diteliti. Populasi dalam penelitian ini adalah semua pasien rawat jalan yang berobat di puskesmas Tempe Kabupaten Wajo, jumlah populasi diperoleh dari jumlah kunjungan rata-rata pasien lama setiap hari pada tahun 2010 yaitu 132 sampel, yang terdiri dari 96 sampel diruang poli umum, sedangkan 36 sampel diruang poli gigi. Jumlah sampel yaitu 33 responden yang sesuai kriteria inklusi

1. Kriteria Inklusi
a. Pasien yang memeriksakan kesehatannya di poliklinik umum dan gigi.
b. Pasien yang berkunjung lebih dari satu kali.
c. Pasien yang memanfaatkan pelayanan keperawatan.
d. Pasien yang mampu menjawab sendiri semua pertanyaan.
e. Pasien bersedia menjadi responden.

2. Kriteria Ekslusi

a. Mengalami gangguan orientasi realita.
b. Pasien tidak bersedia menjadi
responden

\section{Cara Pengumpulan Data}

1. Data Primer

Data Primer diperoleh melalui observasi dan wawancara langsung kepada responden terpilih dengan menggunakan alat bantu kuesioner yang telah disiapkan oleh peneliti.

2. Data sekunder

Data sekunder yaitu diperoleh dari puskesmas, Kelurahan Tempe Kabupaten Wajo, dimana data ini digunakan untuk melengkapi dan menunjang kelancaran penelitian.

\section{Pengolahan Data}

a. Editing Penyuntingan data yang dilakukan setelah semua data terkumpul, kemudian dilakukan pemeriksaan kelengkapan data, kesinambungan data dan keseragaman data.

b. Koding, Untuk memudahkan pengolahan data.

c. Tabulating, untuk memudahkan pengolahan data maka dibuatkan table untuk menganalisis data tersebut menurut sifat-sifat yang dimiiki. Tabel dapat berupa tabel sederhana atau tabel silang

\section{Analisa Data}

Setelah dilakukan tabulasi data, kemudian data diolah dengan menggunakan uji statistik yaitu analisis univariat dilakukan untuk variabel tunggal yang dianggap terkait dengan penelitian dan analisis bivariat untuk melihat distribusi beberapa variabel yang dianggap terkait dan menggunakan uji Chisquare dengan kemaknaan $\alpha=0,05$.

\section{HASIL PENELITIAN}

1. Analisa Univariat

Table 1 Distribusi Responden berdasarkan Umur, Pendidikan Terakhir, Jenis Kelamin dan Ruang Poliklinik Puskesmas Tempe Kabupaten Wajo

\begin{tabular}{|c|c|c|}
\hline Karakteristik & $\mathrm{n}$ & $\%$ \\
\hline Umu & & \\
$15-24$ & 9 & 27,3 \\
$25-34$ & 10 & 30,3 \\
$35-44$ & 11 & 33,3 \\
$45-54$ & 1 & 3,0 \\
$55-64$ & 2 & 6,1 \\
\hline Pendidikan & & \\
Terakhir & & \\
Tamat SD & 2 & 6,1 \\
Tamat SMP & 6 & 18,2 \\
Tamat SMA & 9 & 27,3 \\
Tamat Perguruan & 16 & 48,5 \\
Tinggi (PT) & & \\
\hline Pekerjaan & 9 & 27,3 \\
IRT & 8 & 24,2 \\
Wiraswasta & 6 & 18,2 \\
Pegawai Swasta & 10 & 30,3 \\
PNS & & \\
\hline Jenis Kelamin & & \\
Laki-laki & 16 & 48,5 \\
Perempuan & 17 & 51,5 \\
\hline Ruang Poliklinik & 22 & 66,7 \\
Poli Umum & 11 & 33,3 \\
Poli Gigi & & \\
\hline
\end{tabular}

Berdasarkan tabel 1. menunjukan bahwa hampir setengah responden yaitu 11 responden $(33,3 \%)$ dari 33 responden yang memanfaatkan pelayanan rawat jalan di Puskesmas Tempe berada dikelompok umur 35-44 tahun, sebagian kecil yaitu 3 responden $(9,1 \%)$ berada dikelompok umur 45-54 tahun dan 55-64 tahun, selebihnya yaitu 19 responden $(57,6 \%)$ berada dikelompok umur 15-24 tahun dan 25-34 tahun. Karakteristik pendidikan terakhir resonden, menunjukkan bahwa hampir seteng Analisa Bivariat responden yaitu 16 responden $(48,5 \%)$ dari 33 responden yang memanfaatkan pelayanan rawat jalan di Puskesmas Tempe menamatkan pendidikan diperguruan tinggi, sebagian kecil yaitu 8 responden (24,3\%) menamatkan pendidikan di SD dan SMP, selebihnya yaitu 9 responden $(27,3 \%)$ menamatkan pendidikan di SMA. 
Sedangkan untuk karakteristik pekerjaan responden, menunjukkan bahwa hampir setengan responden 10 responden $(30,3 \%)$ dari 33 responden yang memanfaatkan pelayanan rawat jalan di Puskesmas Tempe yaitu bekerja sebagai PNS, sebagain kecil yaitu 6 responden $(18,2 \%)$ bekerja sebagai pegawai swasta (PS) dan selebihnya yaitu 17 responden $(51,5 \%)$ bekerja sebagai IRT dan Wiraswasta. Sementara itu, untuk karakteristik jenis kelamin menunjukkan bahwa setengah responden yaitu 17 responden $(51,5 \%)$ dari 33 responden yang memanfaatkan pelayanan rawat jalan di Puskesmas Tempe adalah perempuan dan selebihnya yaitu 16 responden (48,5\%) adalah laki-laki. poliklinik menunjukkan bahwa sebagian besar responden yaitu 22 responden $(66,7 \%)$ dari 33 responden yang memanfaatkan pelayanan rawat jalan di Puskesmas Tempe melakukan rawat jalan di poliklinik umum dan selebihnya 11 responden $(33,3 \%)$ di poliklinik gigi

2. Analisa Bivariat

Tabel 2 Distribusi Responden berdasarkan Tingkat Kepuasan Pasien Rawat Jalan dari segi Penampilan Fisik Perawat di Puskesmas Tempe Kebupaten Wajo

\begin{tabular}{|c|c|c|c|c|c|c|}
\hline $\begin{array}{c}\text { Tingkat } \\
\text { Kepuasan } \\
\text { Pasien dari } \\
\text { segi Penam } \\
\text { pilan Fisik }\end{array}$ & \multicolumn{2}{|c|}{$\begin{array}{c}\text { Poliklini } \\
\text { kUmum }\end{array}$} & \multicolumn{2}{|c|}{$\begin{array}{c}\text { Poliklini } \\
\text { Gigi }\end{array}$} & & \\
\hline Tidak & 1 & 3,0 & 1 & 3,0 & 2 & 6,1 \\
$\quad$ Puas & 1 & 54, & 1 & 30, & 2 & 84, \\
Puas & 8 & 5 & 0 & 3 & 8 & 8 \\
Sangat & 3 & 9,1 & - & - & 3 & 9,1 \\
Puas & & & & & & \\
\hline Total & 2 & 66, & 1 & 33, & 3 & 100 \\
& 2 & 7 & 1 & 3 & 3 & \\
\hline
\end{tabular}

Berdasarkan tabel 2 menunjukan bahwa hampir seluruh responden yaitu 28 responden $(84,8 \%)$ dari responden yang memanfaatkan pelayanan rawat jalan di Puskesmas Tempe merasa puas terhadap kualitas pelayanan keperawatan dari segi penampilan fisik perawat dan 3 responden $(9,1 \%)$ merasa sangat puas, selebihnya 2 responden $(6,1 \%)$ merasa tidak puas terhadap pelayanan keperawatan tersebut.

\section{PEMBAHASAN}

Menurut Paluttari (2008) Pelayanan kesehatan yang berkualitas adalah pelayanan kesehatan yang dapat memuaskan setiap pemakai jasa pelayanan kesehatan sesuai dengan tingkat kepuasan rata-rata penduduk serta penyelenggaraannya sesuai dengan kode etik dan standar pelayanan profesi yang ada. Dansky mengatakan bahwa pemuasan pelanggan atau pasien adalah prinsip dasar manajemen mutu kualitas.

1. Tingkat Kepuasan Pasien terhadap Kualitas Pelayanan Keperawatan dari segi Penampilan Fisik Perawat

Dari hasil penelitian menunjukkan bahwa pasien yang memanfaatkan pelayanan rawat jalan di poliklinik umum dan gigi hampir seluruhnya mempersepsikan perasaannya puas terhadap penampilan fisik perawat dan bahkan terdapat beberapa pasien merasa sangat puas. Hal ini terbukti, dengan 28 responden $(84,8 \%)$ merasa puas, 3 responden $(9,1 \%)$ merasa sangat puas sedangkan hanya 1 responden $(3,0 \%)$ merasa tidak puas.

2. Tingkat Kepuasan Pasien terhadap Kualitas Pelayanan Keperawatan dari segi Empaty Perawat

Dari hasil penelitian menunjukkan bahwa pasien yang memanfaatkan pelayanan rawat jalan di poliklinik umum dan gigi hampir seluruhnya mempersepsikan perasaannya puas terhadap empaty perawat yaitu 29 responden $(87,9 \%)$ sedangkan hanya 4 responden $(12,1 \%)$ yang merasa tidak puas.

Hal ini sejalan dengan penelitian yang dilakukan oleh Ernawati (2004), dimana petugas kesehatan berada pada kategori baik meskipun masih ada yang menyatakan tidak baik. Dari penelitian ini menunjukkan bahwa pelayanan yang diberikan oleh petugas kesehatan hampir sesuai dengan harapan. Selain itu, hal ini diperkuat dengan penelitian yang dilakukan Yuliani (2004) pada rawat jalan di Puskesmas Minasa Upa diperoleh bahwa 23 responden $(51,1 \%)$ dari 45 responden menyatakan puas terhadap empaty.

3. Tingkat Kepuasan Pasien terhadap Kualitas Pelayanan Keperawatan dari segi Daya Tanggap Perawat

Dari hasil penelitian menunjukkan bahwa pasien yang memanfaatkan pelayanan rawat jalan di poliklinik umum dan gigi hampir setengah responden mempersepsikan perasaannya puas terhadap daya tanggap perawat yaitu 27 responden $(81,8 \%)$ dan bahkan terdapat satu responden pasien merasa sangat puas. Tergambar dari hasil kuesioner, dimana pasien mempersepsikan perasaannya puas bahkan sangat puas pada pernyataan tentang pemberikan 
pelayanan tepat waktu, perawat segera melayani pasien yang baru tiba, cepat dalam memberikan tindakan keperawatan dan siap terhadap kebutuhan pasien.

4. Tingkat Kepuasan Pasien terhadap Kualitas Pelayanan Keperawatan dari segi Kehandalan Perawat

Dari hasil penelitian menunjukkan bahwa pasien yang memanfaatkan pelayanan rawat jalan di poliklinik umum dan gigi hampir seluruhnya mempersepsikan perasaannya puas terhadap kehandalan perawat yaitu 30 responden $(90,9 \%)$ dan bahkan selebihnya yaitu 3 responden $(9,1 \%)$ pasien merasa sangat puas. Tergambar dari hasil kuesioner, dimana pasien mempersepsikan perasaannya puas dan bahkan sangat puas pada pernyataan kedisiplinan, keefektifan dan kebersihan perawat dalam menjalankan tugasnya yaitu mempersiapkan peralatan sebelum melakukan tindakan keperawatan sesuai dengan prosedur, membina hubungan saling percaya antara perawat dan pasien, komunikasi perawat mudah dimengerti serta kontrak waktu ditetapi perawat.

\section{KESIMPULAN}

1. Tingkat kepuasan pasien terhadap kualitas pelayanan keperawatan dari segi penampilan fisik perawat di Puskesmas Tempe Kabupaten Wajo berada pada kategori puas.

2. Tingkat kepuasan pasien terhadap kualitas pelayanan keperawatan dari segi empaty perawat di Puskesmas Tempe Kabupaten Wajo berada pada kategori puas.

3. Tingkat kepuasan pasien terhadap kualitas pelayanan keperawatan dari segi daya tanggap perawat di Puskesmas Tempe Kabupaten Wajo berada pada kategori puas.

\section{DAFTAR PUSTAKA}

Azizah, 2004. Studi Mutu Pelayanan Kesehatan pada peserta Askes di Ruang Rawat Inap RSUD

Propinsi Sulawesi Tenggara. Skripsi tidak dipublikasikan : Makassar. FKM UNHAS

Depkes RI, 2005. Visi \& Misi Indonesia Sehat 2010 : Jakarta. (http://www.Depkes.Visi/html). Diakses 24 Juni 2010. Pukul 20.00 Wita.

Laporan Tahunan Kunjungan Rawat Jalan Puskesmas Tempe Tahun 2010. Kabupaten Wajo

Pulutturi, Sukri, 2008. Manajemen Mutu Terpadu Staf Penganjar FKM UNHAS. Makassar.

Team FKM UMI, 2010. Panduan Penulisan Proposal Penelitian Skripsi Cetakan Kelima,. FKM UMI : Makassar.

Tihono, 2002. APRIME Pedoman Manajemen Puskesmas. Proyek Kesehatan Keluarga dan Gizi Departemen
4. Tingkat kepuasan pasien terhadap kualitas pelayanan keperawatan dari segi kehandalan perawat di Puskesmas Tempe

\section{SARAN}

1. Bagi Puskesmas Tempe Kabupaten Wajo Diharapkan kepada pihak manajemen Puskesmas Tempe terutama kepala ruang poliklinik umum dan gigi agar tetap dan lebih meningkatkan 作 penampilan fisik, misalnya perawat lebih dalam menghadapi pasien dan (n) keadilan dalam kepada pasien untuk bertanya tentang hal yang tidak diketahuinya. Dari segi daya tanggap, misalnya perawat menjelaskan guna dan dosis obat, membantu tanpa membedakan status, derajat, pekerjaan pasien. Senta dari segi kehandalan, misalnya penyampaian informasi kepada

. Bagi Pendidikan

Diharapkan kepada pihak manajemen Intitusi Keperawatan agar lebih (agi kompetensi mahasiswa penggunaan komunikasi terapiutik.

3. Bagi Masyarakat/Pasien

kepada masyarakat/pasien baik itu berupa saran dan pujian atas pelayanan keperawatan yang diberikan 列 melam meban untuk meningkatkan mutu pelayanan keperawatan di Puskesmas Tempe.

\footnotetext{
Kesehatan : Jakarta.
} 